We are indebted to C. W. Pluygers for synthesizing the chemical compounds, and to G. Meyer for carrying out $a_{0}$ number of biological tests.

G. J. M. VAN DER KERK

M. H. VAN RAALTE

A. KaARs SiJPesteijn

T.N.O.-Z.W.O. Research Team,

Institute for Organic Chemistry T.N.O., Utrecht, and the

Department of Phytopathology,

Agricultural University, Wageningen.

R. VAN DER VEEN

Physical Laboratory,

N.V. Philips,

Eindhoven.

March 17.

1 Van der Veen, R., and Daams, J., Proc. Kon. Akad. v. Wetensch., C, 57,81 (1954)

${ }^{2}$ Veldstra, H., "Ann. Rev. of Plant Physiol.", 4, 151 (1953).

${ }^{3}$ Van der Kerk, G. J. M., and Klöpping, H. L., Rec. trav. chim., 71 1179 (1952).

4 Wain, R. L., Roy. Inst. Chem., Mono. No. 2 (1953); ef. Wain, R. L., J. Sci. Food and Agric., 2, 101 (1951).

\section{Basophilia and High Ribonucleic Acid Content of Dividing $E$. coli Cells}

IN a previous communication ${ }^{1}$, a staining technique was described for demonstrating the wide difference in basophilia of growing and non-growing cells of $E$. coli. The high basophilia of growing $E$. coli cells has been attributed by Belosersky ${ }^{2}$ to the presence of pentose nucleic acid which is not attached to protein. Apart from the work of Belosersky and his collaborators, the nature of the additional ribonucleic acid has received little attention, although it has been known for some years that rapidly growing and dividing cells of bacteria have a substantially higher concentration of ribonucleic acid than resting cells, and there is ample evidence of the heterogeneity of ribonucleic acid in metazoan cells ${ }^{3}$.

To characterize the additional ribonucleic acid in dividing cells of $E$. coli (N.C.T.C. No. 1100) and to determine whether or not it reflects a general increase in the existing complement of constituents containing ribonucleic acid of the cell, the ribonucleic acid of rapidly dividing cells and resting cells of this bacterium were subjected to various fractionations. Dividing cells were obtained from a casein/casein/ yeast eulture 4 during the phase of maximum growth and of rate of division; resting cells were obtained from a fully grown culture.

When disintegrates of these cells were fractionated by centrifugation, it was found that the basophilia of dividing cells was located in the deposit obtained between $25,000 \mathrm{~g}$ and $100,000 \mathrm{~g}$. Chemical analyses revealed that the ribonucleic acid in this fraction exceeded that in the corresponding fraction from resting cells by the difference in the total ribonucleic acid concentration of the unfractionated dividing and resting cells. The coincidence of the additional ribonucleic acid and the basophilia in one fraction lends support to Belosersky's contention that ribonucleic acid is responsible for the high basophilia of these cells. However, the possible heterogeneity of this fraction has not been investigated, and it is not known whether the ribonucleic acid responsible is attached to protein or not. The ribonucleic acid content of the basophilic fraction was approximately
40 per cent ribonucleic acid nitrogen/total nitrogen. This figure was calculated from a determination of the acid-insoluble pentose as determined by Militzer and the ribonucleotide ratio of the whole ribonucleic acid of the cell.

The finding of basophilic and ribonucleic acid-rich particles in dividing bacterial cells is of particular interest in view of the discovery by Petermann et al.$^{\mathbf{8}, \text { ? }}$ of similar submicroscopic particles in chick embryo, regenerating liver and tumours which they detected in the analytical centrifuge at $95,000 \mathrm{~g}$ and believe to be rich in ribonucleic acid. In regenerating liver, Petermann ${ }^{6}$ was able to correlate the high concentration of these particles with rapid cell division.

The identification of the ribonucleic acid-rich particles from dividing $E$. coli cells with those from dividing metazoan cells would support the suggestion made previously ${ }^{8}$ that the additional ribonucleic acid of dividing and growing $E$. coli cells is more directly concerned in the division process than the growth process.

Acknowledgment is made to the Chief Scientist, Ministry of Supply, for permission to publish this communication.

\section{H. E. WADE}

Microbiological Research Department,

Experimental Station, Porton,

Nr. Salisbury, Wilts. March 25.

${ }^{1}$ Wade, H. E., and Morgan, D. M., Nature, 174, 920, 1087 (1954). 2 Belogersky, A. N., Cold Spring Harbor Symp. Quant. Biol., 12, 1 (1947).

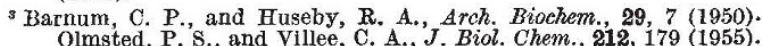
4 Gladstone, G. P., and Fildes, P., Brit. J. Exp. Path., 21, 161 (1940). s Militzer, W. E., Arch. Biochem., 9, 85 (1946).

- Petermann, M. L., Mizen, N. A., and Hamilton, M. G., Cancer Res., 18, 372 (1953).

'Petermann, M. L., Mizen, N. A., and Hamilton, M. G., Proc. Amer. Assoc. Cancer Res., 1, 37 (1954).

${ }^{8}$ Wade, H. F., J. Gen. Mierobiol., 7, 24 (1952).

\section{Anaerobic Metabolism of Thiocyanate by Thiobacilli}

IN 1904, Beijerinck ${ }^{1}$ first described the decomposition of ammonium thiocyanate by Thiobacilli. Thirty-three years later, Happold and $\mathrm{Key}^{2}$ reported the disappearance of thiocyanate from gas liquors due to microbial activity. The thiocyanate-oxidjzing organism was only obtained in pure culture by Happold, Johnstone and Rogers ${ }^{3}$ in 1952. In a subsequent publication, Happold, Johnstone, Rogers and Youatt ${ }^{4}$ characterized the organism finally as a strict autotroph which aerobically oxidized thiocyanate to sulphate, carbon dioxide and ammonia. The organism grew with carbon dioxide as sole source of carbon, and could derive its energy from the oxidation of sulphur and thiosulphate with oxygen as oxidant. The name Thiobacillus thiocyanoxidans was suggested.

The oxidation of thiocyanate by Thiobacilli under anaerobic conditions with nitrate as oxidant was discovered in this laboratory some months ago. It was found that certain strains of Thiobacillus denitrificans isolated from surface water and from corroded sewer concrete were capable of oxidizing thiocyanate with the production of gaseous nitrogen. Strains A3-I and $\mathrm{VI} b-1$, two of six pure cultures examined, when 